CDD: 170

\title{
How to (dis)solve Nagel's paradox about moral luck and responsibility
}

\section{Fernando Rudy Hiller}

Stanford University

Department of Philosophy

450 Serra Mall

Main Quad, Building 90

Stanford, CA 94305, USA

ferudy@stanford.edu

Received: 08.07.2015; Revised: 23.12.2015; Accepted: 28.01.2016

DOI: http://dx.doi.org/10.1590/0100-6045.2016.V39N1.FRH

\begin{abstract}
In this paper I defend a solution to the moral luck problem based on what I call "a fair opportunity account of control." I focus on Thomas Nagel's claim that moral luck reveals a paradox, and argue that the apparent paradox emerges only because he assumes that attributions of responsibility require agents to have total control over their actions. I argue that a more modest understanding of what it takes for someone to be a responsible agent-i.e., being capable of doing the right thing for the right reasonsdissolves the paradox and shows that responsibility and luck aren't at odds.
\end{abstract}

Key words: control; fair opportunity; reasons-responsiveness; responsibility; moral luck; Nagel.

\section{Introduction}

In his classic "Moral Luck" (1979) paper, Thomas Nagel claims that moral luck reveals a paradox in our concept of moral responsibility. The paradox Nagel takes himself to have identified can be summarized as follows. The central element in our concept of moral responsibility is the Condition of Control (henceforth, CC), which can be rendered in schematic form thus: 
(CC) Agent $S$ is morally responsible for action $A$ only if $A$ is under $S$ 's control.

A corollary of the CC is that one isn't responsible for what is beyond one's control, and this is what allows us to say that certain factors like coercion, involuntary movements, and ignorance excuse from responsibility. The paradox arises because once we become aware of the fact that all of what we do depends, at least partially, on factors beyond our control—many of which are due to dumb luck-our notion of responsible agency seems to lack application, and not because we are imposing on it "an arbitrary external requirement" (Nagel 1979, p. 36) but rather because we are just consistently applying its own constitutive standard.

Several responses have been attempted to address Nagel's paradox. They fall in one or another of two camps: on the one hand, defending the CC and rejecting the influence of luck on moral responsibility; on the other, defending the influence of luck on moral responsibility and rejecting the CC. I think neither strategy is satisfactory (I will review and criticize below one important sample of each.) On the contrary, I think that a satisfactory solution to the paradox must vindicate the centrality of the CC and, at the same time, acknowledge the large role played by luck in our moral life. My main goal in this paper is to present an account of responsible agency that meets both desiderata. The strategy I will pursue is to dispute Nagel's assumption that the paradox in question arises "from the nature of moral judgment itself" (Nagel 1979, p. 36) and the underlying conception of control that he presupposes. I will propose an alternative rendering of what moral judgments-more precisely, judgments of responsibility - involve and of the kind of control that judgments so conceived require. It will then be clear that the paradox fails to arise in this alternative conception, and I will offer reasons to prefer it over Nagel's.

\section{The moral luck paradox}

Nagel describes the paradox of moral luck as follows:

A person can be morally responsible only for what he does; but what he does results from a great deal that he does not do; therefore he is not

Manuscrito - Rev. Int. Fill, Campinas, v.39, n.1, pp. 5-32, jan.-mar. 2016. 
morally responsible for what he is and is not responsible for. (This is not a contradiction, but it is a paradox.) (Nagel 1979, p. 34)

The sentence up to the first semicolon can be read as a restatement of the CC, and the sentence up to the second semicolon as a summary of what moral luck shows us. The paradoxical conclusion is that the very condition lying at the heart of the concept of moral responsibility threatens its applicability.

How does Nagel understand the idea "a person can be morally responsible only for what he does" (i.e., the CC) such that the phenomenon of moral luck seems to him to show that moral responsibility is paradoxical? What Nagel has in mind seems to be this: actions can be evaluated as praiseworthy or blameworthy when and only when it is possible for us to trace them back to something we may call the "responsible" or "active" self (henceforth, AS). ${ }^{1}$ This is, in effect, what the CC comes to for Nagel: an agent has control over an action when it is connected in the right way to his AS. ${ }^{2}$ When an action emanates from this self we can judge it (the action) morally, because, as Nagel insists, when we judge the action "[w]e are judging him [the agent], rather than his existence or characteristics" (1979, p. 36). So when we evaluate an action in moral terms we have to make sure that the action is connected in the right way to the agent's AS; otherwise, our moral judgment will miss its target. But now moral luck in its four variants-constitutive, circumstantial, antecedent, and resultant-enters the scene, and what Nagel wants to claim is that once we acknowledge the pervasiveness of luck we are bound to conclude that the connection between action and AS never actually occurs (alternatively, we are bound to conclude that no one is ever really in control of his actions). This is because each of the four types of luck severs in its own way that connection, in much the same way that traditional excusing conditions like coercion or ignorance do.

Let's start with constitutive luck. If the occurrence of an action can be explained, at least in part, in terms of the agent possessing a certain character trait (for instance, sympathy or indifference) so deeply ingrained in him that it makes sense to say that the agent "just is like that," and yet he can intuitively be praised

${ }^{1}$ Nagel (1979) uses the label “active self' at p. 37.

${ }^{2}$ As we will see in section 4.1, it turns out that the only kind of control that can satisfy this condition (i.e., securing an adequate connection between an action and the agent's $\mathrm{AS}$ ) is an extremely demanding one. I will dub it "total control."

Manuscrito - Rev. Int. Fil., Campinas, v.39, n.1, pp. 5-32, jan.-mar. 2016. 
or blamed for the action, we have a case of constitutive luck. The reason why constitutive luck threatens to sever the link between action and AS is that it opens the door to psychological explanations of the form "Jones doesn't donate to charity because of his indifference, and he is like that due to his upbringing" or "Smith always help people because of his innate sympathy." In this kind of explanations, the agent himself seems to recede into the background and what takes center stage is the character trait in question-coupled with an account of how the agent got to be that way. Nonetheless, we don't normally cease to pass moral judgment in these cases; rather, we would still say that Jones's action is blameworthy and Smith's praiseworthy. What's more, some philosophers insist that we could blame Jones for his indifference itself and praise Smith for his sympathy itself. ${ }^{3}$ But once we recognize that who the agent is - in terms of having certain deeply ingrained character traits-isn't something he can control, then our confidence in the link between an act of sympathy or indifference and the AS appears unfounded. Ascribing an action prompted by indifference to the AS instead of to the character trait in question would now seem as irrational as, say, blaming Jones for slapping Smith even after we learn that the slapping was due to an epileptic seizure suffered by the former.

If constitutive luck provides the basis for psychological explanations of actions, circumstantial luck provides the basis for sociological ones. A person is said to be "a victim of the circumstances" when it seems to us that she was in some sense compelled to do what she did in virtue of the particular circumstances of choice in which she found herself in. Conversely, it can be speculated that if this person had lived in different circumstances she would have behaved very differently. The suggestion is, then, that anyone (or almost anyone) would have done what this person actually did if placed in the same situation, and so the link between the action and this agent - the one who actually performed it-seems to vanish. Once again, the agent recedes into the background and now the circumstances are what appear to account for what happened.

In third place comes antecedent (or causal) luck. As Nagel notes (1979, p. 35), it amounts to the threat that causal determinism is sometimes assumed to pose to ascriptions of responsibility: if everything we do-including "strippeddown acts of the will" (idem)—is causally determined by prior events, it seems

${ }^{3}$ For a defense of this claim-focusing on blameworthy attitudes-see Robert Adams (1985). A more recent version can be found in Angela Smith (2005).

Manuscrito - Rev. Int. Fil., Campinas, v.39, n.1, pp. 5-32, jan.-mar. 2016. 
that what really explains the occurrence of any action whatsoever is not the agent that constitutes the final link in an infinitely long causal chain, but that chain itself. If this is so, then once more the connection between action and AS that is supposed to be a condition for ascriptions of responsibility is proved to be illusory.

Finally, resultant luck is the clearest example (from Nagel's perspective) of how weak the link between action and AS appears to be upon reflection. This is because everything we do (besides, perhaps, merely mental actions) is a compound of our intentions and the external world's cooperation. Even for very simple actions like, for example, walking, that I effectively am able to do what I intend to do requires the cooperation of factors beyond my control (e.g., that my muscles respond in the appropriate way). This very general feature of human actions is amplified in morally fraught cases, because we normally pass different moral judgments depending on the outcomes of people's actions. ${ }^{4}$ To resort to the standard case: the negligent driver who kills a child that unexpectedly jumped into the road didn't intend to kill her, and yet we still consider him more blameworthy than an equally negligent driver whose negligence lacked tragic consequences. ${ }^{5}$ But that the child unexpectedly jumped into the road is something entirely beyond the driver's control, and so the connection between the event (the child's death) and the driver's AS appears to be nonexistent, which means that it seems irrational to blame him for what happened—at least as long as we adhere to the CC.

The central point Nagel wants to illustrate with his typology is this: given that the link between action and AS required for ascriptions of responsibility is threatened everywhere by one or another of the four types of luck, we ought to conclude that no one is responsible for anything. But that's not what we conclude; rather, we keep blaming and praising each other as if we could draw a principled distinction between cases in which the action can be traced back to the agent's AS (and so cases in which the agent was in control) and cases in which it cannot. Moreover, our practice of moral evaluation is premised on the cogency

\footnotetext{
${ }^{4}$ As we will see in section 3.1 there are philosophers who deny this claim.

5 Again, this claim is a highly contentious one, but Nagel clearly accepts it. See Nagel (1979, p. 31). For the opposite position see, e.g., Zimmerman (2002), whom I discuss in section 3.1 .
}

Manuscrito - Rev. Int. Fil., Campinas, v.39, n.1, pp. 5-32, jan.-mar. 2016. 
of this distinction. So there is a tension in our concept of moral responsibility (and its application to practice) that amounts to a paradox: on the one hand, we recognize that control — understood as a suitable connection between action and AS-is required for responsibility; on the other, on reflection we must acknowledge that control thus understood is chimerical. So it seems that, by our own lights, we aren't responsible for what we intuitively think we are. ${ }^{6}$

\section{Dealing with the paradox}

There are two general strategies for dealing with Nagel's paradox that have been amply explored in the literature. On the one hand, denying moral luck in order to defend the CC; on the other, fully embracing moral luck while rejecting the CC. In this section I will argue that neither of them is satisfactory, taking one representative proposal from each side as an example. This will open up a middle ground for my account, which both accepts that luck is an ineliminable presence in moral life and at the same time defends the idea that the CC—suitably interpreted - is central for responsibility.

\subsection{Denying moral luck}

The most thorough defender of the first strategy is Michael Zimmerman (2002). ${ }^{7}$ His objective is to show that "one cannot escape responsibility through

\footnotetext{
${ }^{6}$ One can rightly wonder whether this is truly a paradox rather than a skeptical argument or an error theory about judgments of responsibility. I won't elucidate here the differences between these possibilities, and will simply continue to assume with Nagel that we are dealing with a paradox. However, I do note in section 4.2 below the intimate connection between Nagel's paradox and full-blown skepticism about responsibility.

7 Many philosophers have tried to solve Nagel's paradox by denying moral luck. See for example Jensen (1984), Richards (1986), Thomson (1989), Rosebury (1995), and Wolf (2001). See Rosell (2012) for a useful overview and criticism of some of these (and other) positions against moral luck. I focus on Zimmerman's argument because, unlike what most deniers of moral luck do, he offers an account of responsibility judgments from which it follows that all four types of luck-not only resultant or circumstantial luck, which tend to attract the lion's share of attention-are irrelevant to responsibility. (Richards [1986] and Greco [1995] defend positions which have some points in common
} 
luck" (2002, p. 575) and, conversely, that luck cannot add to one's degree of responsibility. He begins by assuming that to be morally responsible "is to be such that there is an 'entry' in one's 'moral ledger' in light of some fact about oneself; one's 'moral record as a person' is affected by this fact" (2002, p. 555). Judgments of responsibility are thus judgments about this moral record, and Zimmerman's driving intuition is that it cannot be affected by luck. ${ }^{8}$ So his task is to show that, despite appearances to the contrary, a person's moral record is impervious to the four types of luck Nagel identifies. In order to do so, he distinguishes between the degree and the scope of an agent's responsibility. The former has to do with how praise- or blameworthy he is, whereas the latter has to do with the things for which he is praise- or blameworthy. His central point is that luck can affect the scope of one's responsibility, but never its degree-which only varies according to actions one freely undertakes or would have freely undertaken.

Take resultant luck: the two negligent drivers mentioned above share the same degree of blameworthiness (since both displayed the same degree of negligence by freely refusing to take precautionary measures), and yet the scope of what they are blameworthy for is different: one of them is responsible for killing a child, whereas the other isn't. However, since differences in scope don't affect the person's moral record, it follows that the two driver's moral record is tainted to the same degree. Cases of circumstantial luck are trickier, since here the comparison might engage a thoroughly abhorrent agent and a saintly one. For instance, imagine that Hans had the bad circumstantial luck of living in Nazi Germany, and suppose that he committed horrible crimes while serving the Nazi regime. Let's stipulate that an otherwise exactly identical person, Georg, who was transferred by his company to Argentina just before the Nazis took over, led an exemplary life there. Zimmerman claims that if it is true of Georg that he would have freely behaved as bad as Hans did but for a fortuitous circumstance over which he had no control (his having being transferred to Argentina), then he and Hans are blameworthy to the same degree. It is true that in this case the scope of

with Zimmerman's.) A very different line of attack consists in offering a debunking explanation of moral luck based on results from empirical psychology. See Domsky (2004). I find this alternative dubious, but I can't discuss it here. For a forceful reply to Domsky, see Statman (2005).

${ }^{8}$ In section 4.4 below I offer a conjecture about the origin of this intuition. 
Georg responsibility is null, but never mind: he still is, in Zimmerman's words, "responsible tout court" (2002, p. 564). ${ }^{9}$ The same reasoning holds if the fortuitous element in question is a constitutive character trait: if Georg would have freely committed horrendous crimes but for the fact that he is naturally compassionate, then he is as blameworthy as blood-thirsty Hans is. ${ }^{10}$

I think there are several problems with this proposal. Let me briefly mention three. First, it isn't clear that the degree/scope distinction is a coherent one, even if we restrict ourselves to cases where it seems to be prima facie plausible, e.g., the negligent drivers' case. It is claimed that the driver who killed a child is responsible for more things than the driver who didn't, despite the fact that both are responsible to the same degree. This implies that the additional thing the unlucky driver is responsible for (the child's death) adds nothing to his "net degree" of responsibility, which in turn implies that he is zero degrees responsible for it. The problem is that the idea that someone can be responsible for something despite being zero degrees responsible for it is incoherent. ${ }^{11}$ Second, even if we concede the coherence of the above distinction, it fails to deliver the result Zimmerman desires, i.e., the complete eradication of luck. The reason is that, when a character trait $\mathrm{X}$ (or a set of such traits) is essential for who the agent is, we cannot make sense of a counterfactual of the form "If the agent lacked X, he would have freely committed wrongdoing," for in that case the agent in question wouldn't exist. And if it is indeed the case that the essential trait (or set of traits) in question led the agent to behave rightly, then it turns out that he escaped responsibility through luck after all. ${ }^{2}$

Finally, Zimmerman's assumption that judgments of responsibility are essentially about a person's moral record is questionable. A plausible alternative

\footnotetext{
${ }^{9}$ Among other things, this means that, if Hans deserves to be punished, so does Georg. See Zimmerman (2002, p. 571).

10 Zimmerman extends his argument to cover antecedent or causal luck. Suppose that the reason why B didn't kill D is that he was, unlike A, causally determined not to do so; still, Zimmerman argues, "[B] is still as responsible as [A], if he would have freely killed [D], had his causal history cooperated” (2002, p. 567).

${ }^{11}$ I owe this objection to Domsky (2004, p. 453, n. 13).

12 Zimmerman (2002, p. 575) does consider this objection but, incomprehensibly to my mind, he dismisses its relevance.
} 
is to think that, when we judge someone blameworthy for something, our central concern isn't whether he controlled every single factor that may have influenced his conduct, but something more prosaic like whether he was capable of avoiding wrongdoing. ${ }^{13}$ If it turns out that we have reasons to prefer this alternative proposal, then the project to eradicate moral luck at all costs is unmotivated.

\subsection{Denying the condition of control}

This second usual strategy is the opposite of Zimmerman's: it consists in fully accepting moral luck and arguing that Nagel's paradox is generated only because he mistakenly assumes that the $\mathrm{CC}$ is an essential element of the ordinary conception of responsible agency. So once we realize that the CC is not part of that ordinary conception, the paradox vanishes. A representative adherent of this strategy is Margaret Walker (1991). Walker claims that the CC is part and parcel of a "noumenal" or "pure" conception of agency stretching back to Kant, according to which agents are only morally assessable for the effects of "that causality which may be identified with the agent itself, e.g. the causality of character or of intention" (1991, p. 23). She then claims that this conception is fundamentally at odds with moral practice, since the latter is premised on the assumption that competent moral agents grasp the fact that they are entangled "in a causally complex world with imperfectly predictable results" (1991, p. 19). Grasp of this fact, Walker continues, is what allows moral agents to exhibit the "virtues of impure agency," such as integrity and dependability in the face of unexpected circumstances resulting, in part, from one's own actions. By contrast, a world of pure agents, who defend "the strict correlation of moral assessment and responsibility with control" (1991, p. 23), would be a world where "people routinely and with justification walk away from the harmful, cruel, or even disastrous results which their actions were critical, even if not sufficient, in bringing about" (1991, p. 25).

Walker's argument against the CC is thus twofold: on the one hand, that such condition is not part of the ordinary conception of responsible agency but, rather, the product of a philosophical fiction, i.e., the noumenal conception espoused by Kant and Nagel. On the other, that a world of such noumenal or

${ }^{13}$ I propose an alternative rendering of judgments of responsibility along these lines in section 4.3 below.

Manuscrito - Rev. Int. Fil., Campinas, v.39, n.1, pp. 5-32, jan.-mar. 2016. 
pure agents - that is, of agents who endorse the CC-would be morally appalling. Both of these points can be disputed, however. Concerning the first, it is simply false that the CC is essentially tied to Nagel's (or, for that matter, Kant's) conception of responsible agency. On the contrary, one can offer an interpretation of the CC that is compatible with the fact of our entanglement "in a causally complex world." Moreover, it can be argued (as I will do in the next section) that this alternative interpretation of the CC is indeed an essential element of the ordinary conception of responsible agency.

Walker's second point can also be disputed. The worry here is that if responsibility is correlated with control, agents are entitled to do nothing to remedy the harmful yet unintended results of their actions. But a defender of the CC isn't committed to this unpalatable result; there are at least two different ways in which he can respond to Walker's worry. First, he can defend the idea that blameworthiness is strictly correlated with control, and yet contend that agents are morally expected to take responsibility for (at least some of) the unexpected consequences of their actions. ${ }^{14}$ Second, he can accept Walker's point that some cases of resultant luck do show that blameworthiness sometimes outruns control, and yet defend the centrality of the CC even in this kind of case. The way to do so is to claim that an agent's blameworthiness increases when a bad (yet unintended) outcome occurs only if the agent had, at a previous time, certain degree of control to prevent its actualization. ${ }^{15}$ In either case, Walker's claim that

\footnotetext{
${ }^{14}$ Wolf (2001) defends the idea that there is a "nameless virtue" that consists in "tak[ing] responsibility for more than what, from a bystander's point of view, would be justly impersonally assigned" (p. 10). So, according to Wolf's position, while two equally reckless drivers deserve equal blame for their negligence (and so are equally responsible "from a bystander's point of view"), it can justly be expected from the one who actually caused a serious accident to take responsibility for it, even though it resulted from something that was outside her control (for instance, a child suddenly crossing the street). In this picture, then, the strict correlation of blameworthiness with control doesn't imply that people would happily walk away from "the harmful, cruel, or even disastrous results" of their actions (Walker 1991, p. 25). Jensen (1984) offers a different version of the idea that equally blameworthy agents can be treated differently in the face of resultant luck.

${ }^{15}$ I develop this idea in section 5.2 below.
} 
the CC is at odds with an attractive picture of moral life doesn't hold. ${ }^{16}$ Thus, her underlying thought that embracing luck forces us to abandon the CC doesn't hold either.

\section{A different approach}

I will now present what I see as a better approach to handle Nagel's paradox: not by trying to decide whether control or luck must give way to the other, but rather by diagnosing what it is that gives rise to the paradox in the first place. I will argue that the paradox is built upon an extremely demanding picture of the "nature" of moral judgments, and that once we reject this picture and adopt a plausible alternative the paradox vanishes.

16 Adams (1985) also attacks the CC on the grounds that it distorts our usual moral practices, in particular the practice of blaming people for their "morally objectionable states of mind" (p. 4) such as unjust anger, jealousy, hatred, and even "corrupt beliefs as well as wrong desires" (idem), over which it's assumed we usually lack voluntary control. I don't have the space to discuss Adams's suggestive paper, so I will just note one obvious problem with his argument: one may well accept that our practices involve the moral assessment of people's states of mind and, more generally, the assessment of people's characters, and yet deny that such assessments amount to judgments of moral responsibility. As many authors have observed (see, for instance, Zimmerman [2002, p. 554]), we should distinguish among different forms that moral assessment can take: we should, for instance, distinguish between judgments of moral responsibility (which Zimmerman labels "hypological judgments") from judgments about virtues and vices (usually called "aretaic judgments"), which are naturally interpreted as judgments about an agent's character of the sort Adams is interested in; and we should distinguish both of them from judgments about moral right, wrong, obligatoriness, permissibility, etc. (usually called "deontic judgments"). With these distinctions at hand, we can readily accept that aretaic judgments are indifferent to considerations of control and freedom (see Slote [1990]), while denying that hypological judgments are equally indifferent to them.

Manuscrito - Rev. Int. Fil., Campinas, v.39, n.1, pp. 5-32, jan.-mar. 2016. 


\subsection{The nature of moral judgment}

Nagel claims that the "skeptical problems" that become apparent as soon as we confront the pervasiveness of luck "arise not from the imposition of an arbitrary external requirement, but from the nature of moral judgment itself" (Nagel 1979, p. 36). It is Nagel's view, then, that something about the very nature of moral judgment is what gets the moral luck paradox going. What exactly is this? He provides the answer in the following passage:

Moral judgment of a person is judgment not of what happens to him, but of him ... We are judging bim, rather than his existence or characteristics. The effect of concentrating on the influence of what is not under his control is to make this responsible self seem to disappear, swallowed up by the order of mere events (idem).

It thus follows from this conception of the nature of moral judgment that anything that merely happens to the agent-anything outside the agent's control—cannot be taken into account when we judge him morally. Particularly, everything due to mere luck must be left out from our judgments. So it follows from (Nagel's conception of) the nature of moral judgment that we shouldn't be able to be morally lucky/unlucky in the way we obviously seem to be. This is why the consistent application of the constitutive requirement of moral judgmentthe CC-seems to undermine moral judgment itself: the latter demands something that cannot be secured, namely, an agent with total control ${ }^{17}$ over everything that has an impact on his actions. (So in effect the Active Self I discussed in section 2 is a self that has — or is expected to have- this kind of allencompassing control.) Call this Nagel's "core argument" for the moral luck paradox. ${ }^{18}$

Nagel's core argument is thus based on a certain conception of the nature of moral judgments. What I will do in order to support my contention

17 Fischer (2012) coined the label “total control” to refer to Galen Strawson's (2002) conception of the kind of control required for responsible agency. I briefly address Strawson's position in section 4.4 below.

${ }^{18}$ I thank an anonymous referee for pressing me to consider Nagel's argument under this light. 
that the paradox can be cleanly sidestepped is to argue that such conception is highly contestable and to provide an alternative. I will also claim that a fair opportunity account of control fits nicely with this alternative.

\subsection{Paradox and skepticism}

Begin by noting the obvious fact that, although Nagel refers generically to the nature of "moral judgment," he is concerned with a species of the latter, namely, judgments of moral responsibility. ${ }^{19}$ This class of judgments is usually identified by its intimate connection to the so-called "reactive attitudes" (Strawson 1962), which include, on the negative side, resentment, indignation, and guilt; and, on the positive side, gratitude, admiration, and pride. These attitudes are thought to be constitutive of responses of moralized praise and blame: when we praise or blame someone, our response is guided by them. And when we judge that someone is praiseworthy or blameworthy, we are judging that the person in question is an appropriate or fitting target of these attitudes. So judgments of responsibility form a class of judgments that have to do with moralized praise and blame and the associated reactive attitudes. Now it is certainly true that this class of judgments seems to presuppose some form of control on the part of the person being judged. When we blame someone for something he did, we assume that the action was (in some sense to be specified) under his control. If we discover that this wasn't the case, then, although we may still experience certain characteristic reactions (dismay, consternation, etc.) concerning what happened, blame and its associated attitudes would seem to be out of place.

Suppose that this picture of what responsibility judgments involve is on the right track and that, as stated so far, constitutes common ground between Nagel and his opponent. Now ask: Do we have any reasons for accepting Nagel's implicit claim that the only form of control that is compatible with judgments of responsibility so conceived is total control? (Recall that this would be the kind of control an agent exhibits when he can control everything that has an impact on his actions, including his character, the circumstances in which he acts, the causal history of his actions and their results.) It won't do for Nagel just to insist that

19 The distinction is relevant because there are different kinds of moral judgments. See note 16 above.

Manuscrito - Rev. Int. Fil., Campinas, v.39, n.1, pp. 5-32, jan.-mar. 2016. 
"Moral judgment of a person is judgment not of what happens to him, but of him" (1979, p. 36), since his opponent can gladly concede this point. That is, the opponent can concede that moral judgments (or, more precisely, judgments of responsibility) are focused on the agent - on what he does rather than on what he merely undergoes. ${ }^{20}$ But conceding this point doesn't establish that such judgments presuppose total control on the agent's part.

So at this point the dialectic seems to face a stalemate. Nagel insists, and his opponent denies, that the presupposition of total control is intertwined with the nature of judgments of responsibility. Is this just a clash of intuitions? I don't think so. To move the discussion forward, consider the following: if Nagel's conception of responsibility judgments is right, a certain form of global skepticism about responsibility follows. ${ }^{21}$ For if we know that judgments of responsibility presuppose total control on the agent's part and, at the same time, we know that total control is, more likely than not, impossible for us (this is the lesson that moral luck teaches us), then the only warranted attitude on our part seems to be to withhold such judgments on the grounds that a necessary condition for them isn't met. ${ }^{22}$

If, as I think it is indeed the case, there is only a small step from Nagel's "paradoxicalism" to global skepticism about responsibility, then this is an excellent reason for questioning the assumptions that fuel the former. At this point I appeal to Randolph Clarke's eminently sane-sounding strategy for dealing with the responsibility skeptic:

The fact that certain proposed principles of responsibility nevertheless convict so many of our attributions of error is reason to suspect those principles. Moral practice is often wiser than theory (Clarke 2014, p. 162).

${ }^{20} \mathrm{I}$ say something in defense of this claim in note 28 below.

${ }^{21}$ Nagel himself mentions in passing the skeptical nature of the problem of moral luck in the passage quoted at the beginning of section 4.1 above. See Nagel (1979, p. 36).

22 See Rosen (2004) for a similar conception of skepticism about moral responsibility. Rosen's skepticism, however, isn't grounded on considerations related to luck but on the assumption that ignorant wrongdoing is much more widespread than usually acknowledged. 
It is true that Nagel's official position doesn't convict our attributions of responsibility of error, but of being paradoxical (or of being grounded on a paradox). Still, I think that the deeply unstable position in which Nagel's argument leaves us-regardless of whether it is "mere" paradox or full-blown skepticism-is a reason to suspect the principles of responsibility he endorses and to look for an alternative. I turn now to this task.

\subsection{The fair opportunity to avoid wrongdoing}

I think Nagel is wrong in assuming that the demand of total control is an intrinsic requirement-part of the nature_of everyday judgments of responsibility. I will now offer what I think is a better rendering of the commitments that constitute the latter. When we are trying to decide whether someone is responsible for something, particularly when blameworthiness is at stake, our central concern seems to be not whether the agent had control over every single factor that may have influenced his action or its results, but whether he could have avoided wrongdoing. This is, of course, a familiar thought - that ascriptions of culpability presuppose the ability to do otherwise. Having an ability of this kind doesn't require, however, total control, nor does it require contracausal freedom. Rather, what it requires is a kind of control that suffices for it to be true that those who possess it have a fair opportunity to avoid wrongdoing. 23

How is this fair opportunity to be understood? Nagel could very well admit the importance of the fair opportunity in question and then insist that only total control affords it. But this, again, would amount to imposing stronger requisites than needed into the "nature" of judgments of responsibility. To see that this is so, consider judgments of praiseworthiness. When we judge that someone is praiseworthy for something, we don't seem to presuppose total control on his part; rather, what we presuppose is simply that the agent did the right thing for the right reasons. If he did, he is praiseworthy-regardless of the fact that many factors that contributed to his acting in a praiseworthy way (for instance, having a good character or finding himself in suitable circumstances) escaped his control. So, by parity of reasoning, when blame rather than praise is at stake, our concern seems to be whether the agent was capable of doing the right

23 Brink and Nelkin (2013) argue that fairness understood in this sense is the central concept in the theory of responsibility.

Manuscrito - Rev. Int. Fil., Campinas, v.39, n.1, pp. 5-32, jan.-mar. 2016. 
thing for the right reasons. ${ }^{24}$ If he was, we conclude that he had a fair opportunity to avoid wrongdoing, and so he is blameworthy for not having taken advantage of it-regardless of the fact that many factors that contributed to his acting wrongly escaped his control.

The fair opportunity in question is, then, intimately related to the possession of the capacity to do the right thing for the right reasons. What is involved in this capacity? Two things: normative competence and situational aptness (Brink and Nelkin 2013). ${ }^{25}$ Normative competence consists in a host of cognitive and volitional abilities that together make an agent a reasons-responsive one: the possession of these abilities allows the agent to recognize and respond to salient moral considerations-not always, of course, but with enough frequency so as to count as a competent moral agent. ${ }^{26}$ On the other hand, situational aptness consists in the agent's situation being such that nothing in it significantly interferes with the deployment of his cognitive and volitional abilities. When normative competence and situational aptness are in place, the agent has responsibility-relevant control over his actions. He is capable of doing the right thing for the right reasons, and so he has a fair opportunity to avoid wrongdoing. If he proceeds to do something wrong, he is a fitting target of blame and associated reactive attitudes. Call this a fair opportunity account of control.

\footnotetext{
${ }^{24}$ Nelkin (2011) argues in this fashion, relying in turn on Wolf (1990).

25 Brink and Nelkin (2013) talk of "situational control" instead of "situational aptness". I prefer the latter label since, on my view, situational aptness is a component of control. Brink and Nelkin's proposal, as well as mine, is inspired by Hart (2008). See the following representative passage: "What is crucial is that those whom we punish should have, when they acted, the normal capacities, physical and mental, for doing what the law requires and abstaining from what it forbids, and a fair opportunity to exercise these capacities" (Hart 2008: 152). My proposal applies the insight contained in this passage to the realm of moral responsibility.

26 Representative philosophers who defend a reasons-responsiveness account of responsible agency include Wolf (1990), Wallace (1994), Fischer and Ravizza (1998), Nelkin (2011), Brink and Nelkin (2013), Vargas (2013), and McGeer and Pettit (2015). The issue of how frequently should an agent recognize and respond to moral reasons to count as morally competent is an especially contentious one. For discussion see Fischer and Ravizza (1998, chs. 2-3), Brink and Nelkin (2013), and Vargas (2013, ch. 7).
} 
Now it is true that there are factors beyond the agent's control that may block attributions of blame, but in the present account this is so only when those factors deprive him of the fair opportunity to avoid wrongdoing. Someone might complain that the fairness invoked here is a very indeterminate notion and of no help in actual practice. But this is not the case; we aren't at a loss concerning which influencing factors deprive the agent of the fair opportunity in question and which don't. This can be seen by noting that normative competence and situational aptness - which together constitute the kind of control that affords a fair opportunity to avoid wrongdoing - are intimately related to the existence of exemptions and excuses. And we have a pretty good grasp of the kinds of factors that exempt and excuse precisely by impairing normative competence or situational aptness.

In the standard way of conceiving the distinction, exemptions show that the person in question fails to possess (at a specific time or in general) a necessary attribute of responsible agency, whereas excuses show that, although the person in question is a responsible agent, he isn't blameworthy for the wrong he committed. Paradigmatic exemptions include insanity, immaturity, and uncontrollable urges; paradigmatic excuses include coercion, duress, and ignorance. Interestingly, the exemptions/excuses dichotomy tracks closely the normative competence/situational aptness dichotomy. In effect, insanity, immaturity, and uncontrollable urges exempt from responsibility because they show that one or another component of normative competence is missing or defective: either the cognitive component (insanity and immaturity) or the volitional one (uncontrollable urges). On the other hand, coercion, duress, and ignorance excuse because they show that something in the agent's situation actively interfered with the deployment of his responsibility-relevant capacities (coercion and duress) or that his situation was such that it could not have been expected of him to be aware of the relevant considerations (ignorance). ${ }^{27}$ The central point for our purposes is that exemptions and excuses work by signaling the lack of either normative competence or situational aptness - a lack which, in turn, suggests the lack of the fair opportunity to avoid wrongdoing.

\footnotetext{
${ }^{27}$ Of course, there are cases of ignorance in which someone works actively to deprive the agent of relevant information, as it occurs in cases of deception. However, most commonly the agent's ignorance doesn't result from anyone's efforts to keep him in the dark; it is simply an unfortunate result of a confluence of fortuitous factors.
}

Manuscrito - Rev. Int. Fil., Campinas, v.39, n.1, pp. 5-32, jan.-mar. 2016. 
This rendering of the factors that our responsibility practices recognize as undermining blameworthiness shows that the absence of total control shouldn't be counted as one of them. And this means that the demand for such inflated form of control mustn't be thought as being part of the nature of judgments of responsibility. If this alternative conception of the latter is correct, then (contrary to Nagel's assumption) we aren't committed to ruling out luck as a significant factor in our moral assessments. On the contrary, we can accept the fact that many factors beyond the agent's control—factors due to mere luckinfluence significantly who he is, what he does, and what the results of his actions are, and yet insist that, because not every such factor deprives him of the fair opportunity to avoid wrongdoing, its mere presence doesn't undermine our rightly holding him responsible for his actions. ${ }^{28}$ In the present conception, then, being morally responsible for something doesn't require complete immunity to luck. Luck can be tolerated up to the point where it ceases to be true that the agent subject to its influence has a fair opportunity to avoid wrongdoing. ${ }^{29}$

\subsection{A place for Nagelian intuitions}

Notice that it won't do for Nagel to insist again at this point that the problem with the present proposal is "its failure to explain how skeptical

\footnotetext{
28 And we can hold this position while accepting Nagel's point that "Moral judgment of a person is judgment not of what happens to him, but of him" (1979, p. 36). In my account, judgments of responsibility are about the agent because they evaluate whether he exercised his responsibility-relevant capacities in the midst of all the factors that influenced his action and that are, in this sense, things that merely happened to him.

${ }^{29}$ Nagel briefly entertains a compatibilist response to his argument broadly along the lines I have suggested here, according to which responsibility "is understood not to exclude the influence of a great deal that [the agent] has not done" (1979, p. 36). The problem, however, is that he caricaturizes compatibilism as being simply an "actualist" position, according to which "one is responsible for what one actually does-even if what one actually does depends in important ways on what is not within one's control" (p. 35). I hope it is clear why my account isn't actualist in this sense: in my account, one is responsible for what one actually does only if one has the right kind of control. If the latter is absent, then one isn't responsible, regardless of how morally repugnant one's deed is.
} 
problems arise" (Nagel 1979, p. 36), for I have argued that such problems arise not from the "nature of moral judgment itself" but from a particular understanding of it that isn't forced upon us as soon as we judge someone responsible for something. Here we can invoke again Clarke's suggestion for dealing with the responsibility skeptic: we have reason to be suspicious of alleged principles of responsibility that entail that many (or all) of our attributions of responsibility are mistaken or paradoxical-particularly if we can provide an alternative interpretation of those principles that vindicates moral practice.

This is not to deny that there is a way of understanding judgments of responsibility that does involve total control. This way is characterized by Galen Strawson (2002, p. 451) as "heaven-and-hell responsibility", the kind of ultimate responsibility according to which "it makes sense to propose that it could be just - without any qualification — to punish some of us with (possibly everlasting) torment in hell and reward others with (possibly everlasting) bliss in heaven." If we understand moral responsibility in this hyperbolic way, then it is true that luck cannot be tolerated at all. For how could it be just to punish someone with everlasting torment if there is something - no matter how insignificant-that escaped his control and that contributed to his doing wrong? So I gladly concede that heaven-and-hell judgments of responsibility do seem to presuppose total control; the important question is whether our everyday, run-of-the-mill judgments are of this heaven-and-hell variety. (This is the important question because Nagel presents the problem of moral luck—which, I have just suggested, is closely related to the issue of whether heaven-and-hell responsibility is possible - as a perfectly general one, that is, as a problem that we must confront as soon as make judgments of responsibility.) And the appropriate answer to this question is, I have argued above, a negative one. For our guiding concern in formulating those everyday judgments seems to be not whether the person in question was the unqualified ultimate source of his conduct but, more modestly, whether the person did the right thing for the rights reasons or, if he didn't, whether he had a fair opportunity of doing so. Thus, although there is a place for Nagelian intuitions concerning the longing for total control, such place isn't found in the very nature of our everyday judgments of responsibility. 30

\footnotetext{
30 See notes 32 and 37 below for a pair of representative passages that illustrate Nagel's intuitions in this regard.
}

Manuscrito - Rev. Int. Fil., Campinas, v.39, n.1, pp. 5-32, jan.-mar. 2016. 


\section{Dissolving the paradox}

The alternative rendering I have offered of the commitments we incur when formulating everyday judgments of responsibility does nearly all the work towards dissolving Nagel's paradox. In this rendering, control and luck aren't utterly incompatible and so the paradox fails to arise. In this section I will finish off the dissolving process by making explicit how a fair opportunity account of control can coexist with luck of the four kinds Nagel identifies and, consequently, why the paradox vanishes.

\subsection{Fair opportunity control and luck}

I argued above that the kind of control that matters for our everyday ascriptions of responsibility (more specifically, for ascriptions of blame) is the control that suffices for it to be true that the agent in question has a fair opportunity to avoid wrongdoing. And I also claimed that luck isn't at odds with possessing this kind of control. To see why, recall that lack of total control isn't among the factors that exempt or excuse from responsibility. This means that our ordinary responsibility practices tolerate a great deal of fortuitous influences on the antecedents and the resultants of our actions. It is only when those influences make it the case that either normative competence or situational aptness - the two constituents of control in my account-are absent or impaired that they acquire the status of exemptions or excuses. So this picture of control offers a principled way of distinguishing, on the one hand, those factors that block ascriptions of responsibility by exempting or excusing and, on the other, those factors that, despite escaping the agent's control and having a recognizable impact on what he does, are compatible with his being a responsible agent.

An important assumption in Nagel's argument for the paradox is precisely that this principled distinction can't be drawn:

And the problem posed by this phenomenon [moral luck] ... is that the broad range of external influences here identified seems on close examination to undermine moral assessment as surely as does the narrower range of familiar excusing conditions [e.g., coercion and ignorance]. If the condition of control is consistently applied, it threatens to erode most of the moral assessments we find it natural to make. (Nagel 1979, p. 26) 
It should be clear at this point that the truth of what Nagel says here depends entirely on interpreting the CC as demanding total control. If, by contrast, we understand the $\mathrm{CC}$ as being satisfied by the conjunction of normative competence and situational aptness, as I have urged we should do, Nagel's contention is false: external fortuitous influences on our agency ${ }^{31}$ and excusing conditions aren't on a par.

Compare, for example, ignorance and circumstantial luck. Ignorance provides an excuse only when, due to certain features of the situation, the agent couldn't have been expected to notice the relevant considerations at play. For example, if I hit you with the door because you were standing behind it, in a situation in which no one could have anticipated that there would be a person standing there, my ignorance of your location fully excuses me from blame. Notice that this is so because we can pinpoint a very specific situational factor that deprived me of the fair opportunity to avoid wrongdoing. Now consider circumstantial luck. Nagel seems to think that circumstantial luck provides a blanket excuse of the form "no one is truly responsible for anything because nobody chooses the circumstances of his action." But the truth of this contention depends, again, on the assumption that total control is what responsible agency requires. In my account, by contrast, whether circumstances excuse has to be decided on a case by case basis, by assessing whether the constituents of control were disrupted by specific situational factors. It is true that usually people cannot choose which moral tests they would have to endure, but that fact by itself doesn't show that what matters for moral responsibility is absent or impaired.

A similar treatment can be given to constitutive luck. Having or lacking certain character traits can certainly make it easier or harder to recognize and respond to moral reasons, but the mere fact that people don't get to choose their characters provides no basis for doubting quite generally whether responsibility judgments are in order. In Nagel's view, a consistent application of the CC entails that attributions of responsibility require people to control who they are to as

\footnotetext{
${ }^{31}$ Nagel includes constitutive luck in the category of "external influences" on our agency, which sounds strange. However, all he means by that is that we lack control over (i.e., we don't get to choose) the central features of our character. Here I stick to Nagel's use of the notion of external influences as encompassing all four types of luck.
}

Manuscrito - Rev. Int. Fil., Campinas, v.39, n.1, pp. 5-32, jan.-mar. 2016. 
deep a level as possible; ${ }^{32}$ in my account, by contrast, no such requirement emerges. Quite the contrary: the control that affords the fair opportunity to avoid wrongdoing is compatible with the fact that, by and large, the central traits of our character aren't up to us. Consider, finally, antecedent luck. Even if we concede that our will is causally influenced (or even determined) by past events, the responsibility-relevant control we have over our actions-rendered as the capacity to guide them in response to moral considerations-is not quite generally threatened. ${ }^{33}$ (Resultant luck poses a different challenge, and I will treat it separately in section 5.2 below.)

In sum, the fair opportunity account of control can distinguish in a principled way between genuinely exempting and excusing conditions (those that disrupt normative competence or situational aptness) and fortuitous external influences on our agency (which provide the background for the exercise of our responsibility-relevant capacities). The fair opportunity account doesn't deny that fortuitous external influences exist, nor does it deny that such influences often play a crucial role in molding who we are and what we do as moral agents. What the account does deny is that the presence of luck poses an indiscriminate threat to the appropriateness of attributions of responsibility, given that it doesn't disrupt by default the control with which our everyday judgments are concerned.

Now I have admitted that in my account people can be morally lucky/unlucky in precisely the way Nagel thinks is at odds with the nature of moral judgment, and so he would insist that I have missed something important. In response, I will simply point out that this insistence on an aspect of a person's moral responsibility that must be immune to luck is an instance of the intuition that judgments of responsibility are necessarily of the heaven-and-hell variety. If this is correct, then Clarke's methodological principle can be invoked one last time at this point: since the heaven-and-hell conception of responsibility breeds

32 In The View from Nowhere, Nagel writes: "What we hope for is not only to do what we want given the circumstances, but also to be as we want to be, to as deep a level as possible, and to find ourselves faced with the choices we want to be faced with, in a world that we can want to live in" (1986, p. 136, italics added). My main point in this paper has been that aspirations like these shouldn't be taken as essential for moral responsibility.

33 Several authors endorse the idea that reasons-responsiveness is compatible with determinism. In addition to the authors referred to in footnote 26 above, see also Kane (1996) and Pereboom (2001).

Manuscrito - Rev. Int. Fil., Campinas, v.39, n.1, pp. 5-32, jan.-mar. 2016. 
paradox and skepticism, we have reason to suspect the principles on which it is grounded and to prefer an alternative that vindicates our everyday practice of holding each other responsible.

\subsection{Resultant luck}

I will now explain briefly how I think a fair opportunity account of control should handle cases of resultant luck. These cases pose a difficult problem for control accounts quite generally, because it seems prima facie plausible that in this sort of case responsibility (i.e., blameworthiness) outruns control, no matter how the CC is rendered. ${ }^{34}$ To return to the standard example, now interpreted in light of my account: the negligent driver who paid no heed to the reasons he had for checking his brakes and as a consequence killed a child seems to be more blameworthy than an exactly similar negligent driver who didn't kill a child. In both cases, however, that a child crossed or failed to cross the negligent drivers' respective paths is completely independent from the negligence the two drivers displayed in paying no heed to the relevant reasons. So, how can it be rational to blame one of them more than the other?

Two points are crucial here. First, we should notice that cases like this aren't a source of wholesale skepticism about responsibility of the sort Nagel presents. While it is true that all of what we do involves a certain degree of resultant luck, ${ }^{35}$ not all cases of resultant luck are on a par. Cases of resultant luck that are culpability-generating are those in which it is reasonable to expect of the agent that he foresees the potentially negative consequences of engaging in

\footnotetext{
${ }^{34}$ However, as I indicated at the end of section 3.2, it is also plausible to hold fast to the idea that responsibility cannot outrun control and, consequently, claim that the two negligent drivers are equally blameworthy regardless of the fact that the negligence of one of them had terrible consequences. At the same time, and as I explained in footnote 14 above, some philosophers who defend this idea (e.g., Jensen [1984] and Wolf [2001]) don't think that equal blameworthiness warrants equal treatment in this kind of case. For a defense of the contrary position, according to which the negligent driver who causes a death is indeed more blameworthy, see Moore (2009, pp. 30 and ff.). I side with Moore's position, as I make clear in the text below.

35 In the sense that all of what we do requires the cooperation of factors beyond our immediate volitional control in order for us to execute the actions that we intend to.
}

Manuscrito - Rev. Int. Fil., Campinas, v.39, n.1, pp. 5-32, jan.-mar. 2016. 
certain kind of behavior. So, for example, it is reasonable to expect of the negligent driver that he foresees an obvious possible result of his negligence, namely, that he may be involved in a situation in which optimally functioning brakes would be needed-precisely the ones he would lack. Given this commonsense criterion for ascribing bad consequences to an agent and blaming him for them, the control theorist can make room for cases of resultant luck while at the same time keeping at bay the temptation to conclude that our responsibility practices involve a deep incoherence.

The second point is that, as I have just suggested, a perfectly legitimate option for a control theorist is just to bite the bullet and accept that cases of resultant luck do show that responsibility sometimes outruns control. That is, he can accept the idea that, where bad resultant luck is involved, our blaming practices track actual harms over and above what strictly speaking was under the agent's control — subject, of course, to the commonsense criterion mentioned in the previous paragraph. However, I don't think that this is a damaging concession on the control theorist's part, for two reasons. First, as I just explained, this concession doesn't open the door to blanket skepticism about responsibility. Second, the commonsense criterion is itself control-friendly, since it invokes a previous moment in which relevant considerations were disregarded by the agent plus the assumption that it is reasonable to expect of him to have foreseen the possible consequences of doing so. So, in effect, resultant luck has an impact on the agent's blameworthiness only if he had, at a previous time, certain degree of control over the outcomes in question. Therefore, a control account can accommodate cases of resultant luck without opening the door to either paradox or skepticism and without giving up the centrality of the CC. 36

\footnotetext{
36 An anonymous referee wonders why my account, which is premised on the centrality of the CC, isn't simply a variant of the Kantian view on responsibility. My treatment of resultant luck suffices for dispelling this impression, since Kant would never accept that an agent's blameworthiness could vary according to results beyond his control. Besides, Kant's view on responsibility assumes the existence of a noumenal self outside the causal world, while I have assumed nothing of that sort. On the contrary, and as I explained at length in sections 4.3, 5.1, and in this one, in my account the responsible agent is thoroughly immersed "in a causally complex world with imperfectly predictable results" (Walker 1991, p. 19).
} 


\subsection{The paradox vanishes}

If one accepts the rendering I have given of the nature of judgments of responsibility, and of the kind of control required by it, it should be clear that there is no paradox lying at the heart of our concept of responsibility. Once we keep in mind that the CC doesn't necessarily imply an impossible demanding standard of sourcehood ${ }^{37}$ and control-impossible demanding precisely in view of the broad range of external influences on persons - we can see that the CC doesn't bite its own tail. The reason is precisely the one I defended in 5.1 above, namely, that the interpretation of the CC as the fair opportunity to avoid wrongdoing can draw a principled distinction between genuinely excusing (and exempting) conditions and background external influences, thereby blocking Nagel's central point that "If the condition of control is consistently applied, it threatens to erode most of the moral assessments we find it natural to make" $(1979$, p. 26). Nagel arrives at this conclusion because he sees the following as the relevant questions the CC prompts us to ask: "Are we ever the ultimate source of our actions?" "Do we ever have total control over them?" He thinks that moral luck forces us to answer both questions negatively, thereby generating the paradox. In the alternative picture I have sketched, the relevant questions suggested by the CC are instead: "Is the agent capable of doing the right thing for the right reasons?" "Does he have a fair opportunity to avoid wrongdoing?" And, as I have explained, moral luck doesn't offer any basis for a thoroughgoing skepticism concerning these questions, and so no paradox arises. ${ }^{38}$

\footnotetext{
${ }^{37}$ See this other passage from The View from Nowhere, where Nagel claims that our capacity to view ourselves from outside "encourages our aspirations of autonomy by giving us the sense that we ought to be able to encompass ourselves completely, and thus become the absolute source of what we do" (1986, pp. 117-8, italics added). Again, my main point has been that this aspiration, however legitimate, shouldn't be taken as a necessary component of responsible agency.

38 I thank Manuel Vargas, Jorah Dannenberg, and two anonymous referees for their comments on a previous version of this paper.
}

Manuscrito - Rev. Int. Fil., Campinas, v.39, n.1, pp. 5-32, jan.-mar. 2016. 


\section{References}

ADAMs, R. "Involuntary Sins," The Philosophical Review, 94, pp. 3-31, 1985.

Bratman, M. Intention, Plans, and Practical Reason, Cambridge MA, Harvard University Press, 1987.

BRINK, D. \& D. NELKIN "Fairness and the Architecture of Responsibility," in David Shoemaker (ed.), Oxford Studies in Agency and Responsibility, Vol. 1. Oxford: Oxford University Press, 2013.

Clarke, R. Omissions: Agency, Metaphysics, and Responsibility. Oxford: Oxford University Press, 2014.

Domsky, D. "There is No Door: Finally Solving the Problem of Moral Luck," The Journal of Philosophy, 101, pp. 445-464, 2004.

FIsCHER, J. "Sourcehood: Playing the Cards That Are Dealt You," in Deep Control: Essays on Free Will and Value, Oxford, Oxford University Press, 2012.

\& M. RavizZa Responsibility and Control: A Theory of Moral Responsibility, Cambridge, Cambridge University Press, 1998.

Greco, J. "A Second Paradox Concerning Responsibility and Luck", Metaphilosophy, 26, pp. 81-96, 1995.

HART, H.LA. "Negligence, Mens Rea, and Criminal Responsibility," in Punishment and Responsibility: Essays in the Philosophy of Law, $2^{\text {nd }}$ ed., Oxford, Oxford University Press, 2008.

JENSEN, H. “Morality and Luck”, Philosophy, 59, pp. 323-330, 1984.

KANE, R. The Significance of Free Will, New York, Oxford University Press, 1996.

McGeER, V. and P. Pettit. "The Hard Problem of Responsibility," in DAVID Shoemaker (ed.), Oxford Studies in Agency and Responsibility, Vol. 3, Oxford: Oxford University Press, 2015.

MoOre, M. Causation and Responsibility: An Essay in Law, Morals, and Metaphysics, Oxford, Oxford University Press, 2009. 
NAGEL, T. "Moral Luck," in Mortal Questions, Cambridge, Cambridge University Press, pp. 24-38, 1979.

NAgel, T. The View from Nowhere, Oxford, Oxford University Press, 1986.

NELKIN, D. Making Sense of Freedom and Responsibility, Oxford, Oxford University Press, 2011.

Pereboom, D. Living Without Free Will, Cambridge, Cambridge University Press, 2001.

Richards, N. “Luck and Desert,” Mind, 95, pp. 198-209, 1986.

Rosebury, B. "Moral Responsibility and 'Moral Luck'," The Philosophical Review, 104, pp. 499-524, 1995.

RosELL, S. "El argumento contra la suerte moral: articulación y respuesta," Crítica, 44, pp. 3-33, 2012.

Rosen, G. "Skepticism about Moral Responsibility," Philosophical Perspectives 18, pp. 295-313, 2004.

Slote, M. "Ethics without Free Will," Social Theory and Practice, 16, pp. 369-83, 1990.

SMITH, A. "Responsibility for Attitudes: Activity and Passivity in Mental Life," Ethics, 115, pp. 236-271, 2005.

Statman, D. "Doors, Keys, and Moral Luck: A Reply to Domsky," The Journal of Philosophy, 102, pp. 422-436, 2005.

Strawson, P. "Freedom and Resentment," Proceedings of the British Academy 48, pp. 1-25, 1962.

STRAwSON, G. "The Bounds of Freedom," in R. Kane (ed.) The Oxford Handbook of Free Will, Oxford: Oxford University Press, 2002.

Thomson, J. J. “Morality and Bad Luck,” Metaphilosophy, 20, pp. 203-221, 1989.

VARgas, M. Building Better Beings: A Theory of Moral Responsibility, Oxford, Oxford University Press, 2013.

Walker, M. "Moral Luck and the Virtues of Impure Agency," Metaphilosophy, vol. 22, pp. 14-27, 1991. 
Wallace, J. Responsibility and the Moral Sentiments, Cambridge MA, Harvard University Press, 1994.

Wolf, S. Freedom within Reason, Oxford, Oxford University Press, 1990.

“The Moral of Moral Luck," Philosophic Exchange, 31, pp. 2-16, 2001.

Zimmerman, M. "Taking Luck Seriously," The Journal of Philosophy, 99, pp. 553576. 2002. 